\title{
Distribution of Fatty Acids in the Longissimus Muscle of Holstein Steers during the Fattening Period
}

\author{
Kyohei OzuTsumi, Ken Ito* and Takatomo KAWANISHI ** \\ National Grassland Research Institute, Nishinasuno-cho, \\ Tochigi-ken 329-27 \\ *Chibaken Animal Husbandry Center, Yatsukaido-cho, \\ Chiba-ken 289-11 \\ **Kanagawaken Animal Husbandry Research Institute, \\ Hongo Ebina-shi, Kanagawa-ken 243-04
}

(Received February 24, 1982)

\begin{abstract}
In order to study the distribution of and the changes in composition of fatty acids in the longissimus muscle, seven Holstein steers were fattened for 100-day ( 3 steers) and 200-day (4 steers) periods after being grazed. Samples of each longissimus muscle of the 4 th, $6 \mathrm{th}, 8 \mathrm{th}, 10$ th and 12 th thoracic vertebrae sections and of the 1 st, $3 \mathrm{rd}$ and 5 th lumbar vertebrae sections were taken for determining fatty acid composition of total lipids. There were no statistical differences in the fatty acid composition of the longis simus muscle sections between the 100-day and 200-day fattened steers. However, C18:0 was observed to decrease slightly and C $18: 1$ to increase slightly during the second 100day fattening period. The portions of longissimus muscle from the 4 th, $6 \mathrm{th}, 8$ th and 10 th thoracic vertebrae sections were found to have more $\mathrm{C} 16: 0$ and $\mathrm{C} 18: 0$ and less $\mathrm{C} 16: 1, \mathrm{C} 18: 1$ and total unsaturated fatty acid than the portions from the 12 th thoracic vertebrae and from the $1 \mathrm{st}, 3 \mathrm{rd}$ and 5 th lumbar vertebrae sections. This difference in fatty acid distribution may be related to differences in growth rate within the longissimus muscle.

Jpn. J. Zootech. Sci., 53 (8): 559-564, 1982
\end{abstract}

A number of studies have been conducted regarding the relationships in fatty acids composition within various muscle during growth periods ${ }^{1-6}$. During the growth and fattening of cattle the amounts of intramuscular lipids increase markedly ${ }^{7}$. This increase is predominately in neutral lipids, especially the triglyceride portions, while the relative amounts of phospholipids remain nearly constant ${ }^{8,8,9)}$.

Physiological, biochemical and histological properties of individual muscles are known to vary greatly. These characteristics depend on the fatty acid composition of the muscle. The difference in fatty acid composition in muscle effects the taste of the meat ${ }^{10}$. The fatty acid composition has been found to differenciate by age ${ }^{3,4}$, season $^{3)}$, sex $^{2,6)}, \operatorname{diet}^{4-6)}$ and by the differences between various muscles ${ }^{9-12)}$ and within the muscle itself ${ }^{13)}$.

In our previous report ${ }^{15}$, the differences in the fat content of longissimus muscle sections were found to be related to differences in their growth rate. Distribution of fatty acids in longissimus muscle and changes in fatty acids during the fattening period were examined in the study reported by this paper. 


\section{Materials and Methods}

The seven Holstein steers used in this experiment are described in our previous report ${ }^{15}$. These animals were fattened for 100-day ( 3 steers) and for 200-day ( 4 steers) periods after being grazed and then slaughtered. Each longissimus muscle sample, after being taken from the carcasses, was cut into thoracic and lumbar vertebrae sections. The 4 th, 6 th, 8 th, 10 th and 12 th thoracic vertebrae sections and the $1 \mathrm{st}$, $3 \mathrm{rd}$ and 5 th lumbar vertebrae sections were used for the determination of fatty acid composition after dehydration. Total lipid extraction was performed by the general method, utilizing chloroform and methanol solvents ( $\mathrm{v} / \mathrm{v} 2: 1)$. After extraction, excess solvent was evaporated off under a stream of nitrogen. Esterification of fatty acids was carried out as follows. Extracted fat was methylated by $\mathrm{HCl}$-anhydrous methanol in screw cap tubes and heated in boiling water for 3 hours.

The methylated fatty acids were then extracted by hexane and washed in a $2 \%$ $\mathrm{KHCO}_{3}$ solution. The methyl esters were recovered by extraction of the residue remaining after evaporation of the solvents.

The methylated samples were injected into a Shimazu GC-6A gas chromatograph equipped with a flame ionization detector and a chromatopac. A $250 \mathrm{~cm}$ glass column was packed with $5 \%$ diethylene glycol succinate on a $80 / 100$ mesh chromosorb W support system. The column temperature was $190^{\circ} \mathrm{C}$, both detector and injection temperatures were $230^{\circ} \mathrm{C}$. A nitrogen flow rate of $60 \mathrm{ml} / \mathrm{min}$ was maintained. Individual fatty acid peaks were identified by comparison of retention times with those of known mixtures of standard fatty acids run under the same operating conditions.

Although as many as 17 peaks were present in the chromatograms, only 11 fatty acids were selected to test the experimental variables. They were myristic (C 14:0), myristoleic (C 14:1), pentadecanoic (C 15:0), palmitic (C 16:0), palmitoleic (C 16:1), margaric (C 17:0), heptadecanoic (C 17:1), stearic (C 18:0), oleic (C 18:1), linoleic (C 18:2) and linolenic (C 18:3) acids. Relative fatty acid values were calculated by the chromatopac equipment. All fatty acids were expressed as percentages of the total eleven fatty acids evaluated.

\section{Results and Discussion}

1. Changes in fatty acid composition in the longissimus muscle during fattening. Significant differences of fatty acid composition were not found in the longissimus muscle between the 100-day and 200-day fattened steers (Tables 1 and 2). Sum of the major fatty acids (C 16:0, C 16:1, C 18:0 and C 18:1) was observed to be approximately $92 \%$ in total fatty acids, showing the same trend as the results reported by many workers ${ }^{1.69 .10 .12)}$. In the four fatty acids, however, C 18:0 was observed to decrease slightly and $\mathrm{C} 18: 1$ to increase slightly during the second fattening period. It is well-known that the fatty acid composition of muscle is influenced by age ${ }^{3,4}$, nutrition ${ }^{4-6)}$, exercise ${ }^{111}, \operatorname{sex}^{2.6)}$, season ${ }^{3)}$ and is different among various muscles ${ }^{9-12)}$ and the location of the sample portion ${ }^{13}$. 
Distribution Fatty Acids in Longissimns Muscle

Table 1. The means of fatty acid contents in longissimus muscle sections of cattle finished on 100-day fattening periods after grazing $(n=3)$

\begin{tabular}{|c|c|c|c|c|c|c|c|c|c|c|}
\hline & \multicolumn{5}{|c|}{ Thoracic vertebrae } & \multicolumn{3}{|c|}{ Lumbar vertebrae } & \multicolumn{2}{|c|}{ All sections } \\
\hline & 4 th & 6 th & 8 th & 10 th & 12 th & $1 \mathrm{st}$ & $3 \mathrm{rd}$ & 5 th & Mean & S D \\
\hline C 14:0 & 2.4 & 2.3 & 2.2 & 2. 2 & 2.2 & 2.1 & 2.2 & 2.2 & $2.2 \pm$ & 0.1 \\
\hline C 14:1 & 0.6 & 0.6 & 0.6 & 0.6 & 0.7 & 0.7 & 0.8 & 0.8 & $0.7 \pm$ & 0.1 \\
\hline C 15:0 & 0.8 & 0.6 & 0.9 & 1.1 & 0.8 & 0.9 & 0.8 & 0.9 & $0.9 \pm$ & 0.1 \\
\hline $\mathrm{C} 16: 0$ & 28.2 & 27.7 & 27.7 & 27.7 & 26.5 & 26.9 & 27.1 & 26.1 & $27.2 \pm$ & 0.7 \\
\hline Ci16:1 & 3.9 & 3.7 & 3.7 & 4.0 & 4.5 & 4.5 & 4.4 & 4.9 & $4.2 \pm$ & 0.4 \\
\hline $\mathrm{C} 17: 0$ & 0.7 & 0.8 & 0.7 & 0.7 & 0.9 & 0.7 & 0.6 & 1.0 & $0.8 \pm$ & 0.1 \\
\hline C 17:1 & 0.5 & 0.6 & 0.6 & 0.8 & 0.7 & 0.7 & 0.6 & 1.0 & $0.7 \pm$ & 0.2 \\
\hline C 18:0 & 19.2 & 20.4 & 20.1 & 18.6 & 17.7 & 17.2 & 16.9 & 16.1 & 18. $3 \pm$ & 1.5 \\
\hline C 18:1 & 41.0 & 40.7 & 40.6 & 40.8 & 42.5 & 43.0 & 42.8 & 43.2 & $41.8 \pm$ & 1. 1 \\
\hline C 18:2 & 2.7 & 2.5 & 2.8 & 3.4 & 2.9 & 3.1 & 3.2 & 3.3 & $3.0 \pm$ & 0.3 \\
\hline C 18:3 & 0.2 & 0.2 & 0.2 & 0.3 & 0.6 & 0.2 & 0.5 & 0.5 & $0.3 \pm$ & 0.2 \\
\hline $\begin{array}{l}\text { Total } \\
\text { saturated }\end{array}$ & 51.1 & 51.7 & 51.5 & 50.2 & 48. 1 & 47.8 & 47.6 & 46. 2 & $49.3 \pm$ & 2.0 \\
\hline $\begin{array}{l}\text { Total } \\
\text { unsaturated }\end{array}$ & 48.9 & 48.3 & 48.5 & 49.8 & 51.9 & 52.2 & 52.4 & 53.8 & $50.7 \pm$ & 2.0 \\
\hline
\end{tabular}

Fatty acid contents are expressed as a percent of the total.

Table 2. The means of fatty acid contents in longissimus muscle sections of cattle finished on 200-day fattening periods after grazing $(n=4)$

\begin{tabular}{|c|c|c|c|c|c|c|c|c|c|c|}
\hline & \multicolumn{5}{|c|}{ Thoracic vertebrae } & \multicolumn{3}{|c|}{ Lumbar vertebrae } & \multicolumn{2}{|c|}{ All sections } \\
\hline & 4 th & 6 th & 8 th & 10 th & $12 \mathrm{th}$ & 1 st & $3 \mathrm{rd}$ & 5 th & Mean & S D \\
\hline C 14:0 & 2.6 & 2.6 & 2.6 & 2.7 & 2.9 & 2.6 & 2.6 & 2.6 & $2.6 \pm$ & 0.1 \\
\hline C 14:1 & 0.9 & 0.8 & 0.9 & 0.8 & 1.0 & 1.1 & 1.1 & 1.0 & $1.0 \pm$ & 0.1 \\
\hline C 15:0 & 0.4 & 0.3 & 0.5 & 0.5 & 0.5 & 0.5 & 0.5 & 0.5 & $0.5 \pm$ & 0. 1 \\
\hline C $16: 0$ & 27.9 & 27.9 & 28.0 & 28.6 & 28. 1 & 27.5 & 27.0 & 26.9 & $27.7 \pm$ & 0.5 \\
\hline C 16:1 & 4.1 & 4.1 & 4.1 & 4.1 & 4. 7 & 4.9 & 4.9 & 4.9 & $4.5 \pm$ & 0.4 \\
\hline C 17:0 & 1.1 & 1.1 & 1.0 & 0.8 & 0.8 & 0.9 & 1.0 & 0.9 & $1.0 \pm$ & 0.1 \\
\hline C 17: 1 & 0.7 & 0.7 & 0.7 & 0.6 & 0.8 & 0.7 & 0.7 & 0.8 & $0.7 \pm$ & 0.1 \\
\hline C 18:0 & 17.8 & 18.4 & 18.1 & 17.9 & 16.0 & 15.3 & 15.4 & 15.3 & $16.8 \pm$ & 1.3 \\
\hline C 18:1 & 42.3 & 41.6 & 42.0 & 41.9 & 43.4 & 44.3 & 44.7 & 45.0 & $43.2 \pm$ & 1.3 \\
\hline C 18:2 & 2.0 & 2.3 & 2.0 & 2.0 & 1.9 & 2. 3 & 2.0 & 2. 2 & $2.1 \pm$ & 0.2 \\
\hline C 18:3 & 0.4 & 0.4 & 0.4 & 0.5 & 0.0 & 0.2 & 0.7 & 0.1 & $0.3 \pm$ & 0.2 \\
\hline $\begin{array}{l}\text { Total } \\
\text { saturated }\end{array}$ & 49.7 & 50.3 & 50.2 & 50.4 & 48.3 & 46.7 & 46.5 & 46.0 & 48. $5 \pm$ & 1.8 \\
\hline $\begin{array}{l}\text { Total } \\
\text { unsaturated }\end{array}$ & 50.3 & 49.7 & 49.8 & 49.6 & 51.7 & 53.3 & 53.5 & 54.0 & $51.5 \pm$ & 1.8 \\
\hline
\end{tabular}

Fatty acid contents are expressed as a percent of the total.

Most workers reported that $\mathrm{C} 18: 1$ increased with increasing age and fattening ${ }^{1,2}$ 4,6.11). While, some workers reported that it decreased with increasing age ${ }^{3,14}$. So there is obviously a difference in the results obtained by different workers. As to age and season, the steers were slaughtered at different chronological ages and different seasons, that is, the 100-day fattened steers were slaughtered in the summer and the 
200-day fattened steers in the autum. LinK et al. ${ }^{3)}$ reported that differences in fatty acid composition during growth were related to the season of the year rather than to the chronological age of the animals and that the total amount of saturated fatty acids was highest during the spring and early summer. This observation is in agreement with our results. So we concluded that age and season contribute to fatty acid composition in muscle.

As to the feed, in the present trials comparisons were made using the same breed (Holstein) and fed almost the same feed, mainly concentrates, until finishing. The fatty acid composition in the muscle was similar in both groups of steers. There was almost the same fatty acid composition of the longissimus muscles in this study and in those reported by OTAKE et al. ${ }^{12}$, in spite of the differences in the type of cattle. In making a comparison of this study and their results, it is seen that the management of the animals was almost the same from rearing to finishing since they were both managed at the Grassland Research Institute.

Furthermore, DAvid et al. ${ }^{6}$ ) showed that the muscle of grass-fed animals contained more saturated fatty acids and less unsaturated fatty acids. From this suggestion, the feed may be a main factor influencing fatty acid composition, especially concentrates may cause an increase in the proportion of $\mathrm{C} 18: 1$ in muscle during fattening. How ever, the slight change of fatty acid composition during the second fattening period is not thereby clearly explanined.

2. The distribution of fatty acids within longissimus muscle.

During the fattening period studied, the relative proportion of fatty acids showed only small changes among the longissimus muscle sections. As the averages of all seven steers for each section, the main fatty acid compositions are shown in Fig. 1. There were some tendencies of fatty acid distribution in the longissimus muscle. The portions of longissimus muscle in the 4 th, 6 th, 8 th and 10 th thoracic vertebrae sections have more $\mathrm{C} 16: 0$ and $\mathrm{C} 18: 0$ and less $\mathrm{C} 16: 1, \mathrm{C} 18: 1$ and total unsaturated fatty acids than the portions in the 12 th thoracic and 1 st, 3 rd and 5 th lumbar vertebrae as shown in Fig. 1.

As to longissimus muscle growth, the portions in the 12 th thoracic and the 1 st, $3 \mathrm{rd}$ and 5 th lumbar vertebrae showed greater growth rates than the portions in the 4 th, 6 th and 8 th thoracic vertebrae sections during the second fattening period as reported in our previous paper ${ }^{15}$.

The longissimus muscle consists of two parts, longissimus thoracic and lumbar, which can not be divided into two clear portion. Considered from the standpoint of fatty acid distribution and muscle growth, the two portions have slightly different muscle characteristics an may have a different metabolic activity as reported by ALLEN et $a$ l. $^{16}$. Differences in fatty acids in the two portions of the muscle may be related to the muscle growth rate. So the muscle growth may be related to the fatty acid compasition and the difference of fatty acids composition in muscle may be explained on the basis of a greater degree of metabolic activity in the muscle and its subsequent utilization of lipid as reported by TERREL and BRAY ${ }^{9}$. 

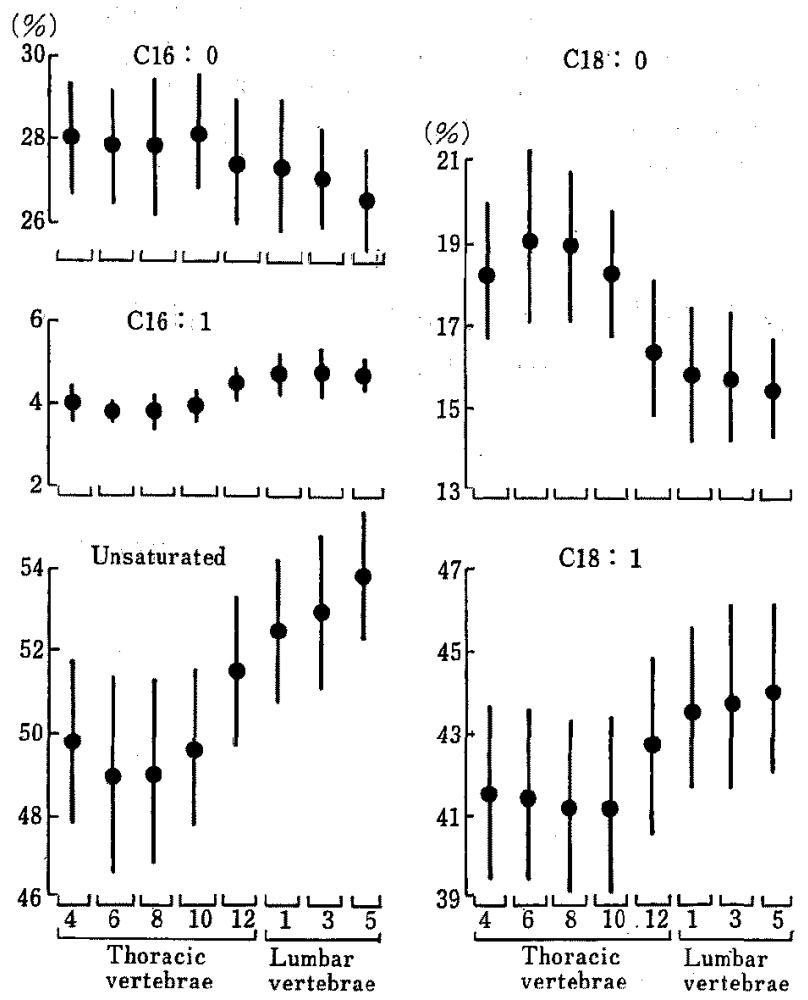

Fig. 1. Distribution of C 16:0, C 16:1, C 18:0, C 18:1 and total unsaturated fatty acids in the longissimus muscle of fattened steers $(n=7)$. Each fatty acid contents is expressed as a percent of the total and is combined for the two groups of steers. Each vertical bar indicates standard deviation.

\section{Acknowledgements}

We are grateful to Mr. T. Yamazaki, Dr. N. Takano, Mr. S. Masaoka and Dr. Y. OHYama of the National Grassland Research Institute for supporting this experiment.

\section{References}

1) Tsuchiya, H., T. Nishino, R. Fukuhara and T. Yamazaki, Bull. Chugoku Agr. Exp. Station, B-13: 21-29. 1965.

2) Waldman, R. C., G.G. Suegss and U.H. Brungrandt, J. Anim. Sci., 27: 632-635. 1968.

3) Link, B. A., R. W. Bray, R. G. Cassens and R. G. Kauffman, J. Anim. Sci., 30: 726-731. 1970.

4) Clements, E., V.Arthamd, R. Mandigo and W. Woods, J. Anim. Sci., 37: 1326-1331. 1973.

5) Skelley, G. C., R. L. Edwards, F. B. Wardlaw and A. K. Torrence, J. Anim. Sci, 47: 11021108. 1978 .

6) David, B. W. and H. B. Hedrick, J. Anim. Sci., 48: 1343-1348. 1979.

7) Ozutsumi, K., M. Okada, N. Kawakami and A. Shinohara, Bull. Natl. Grassl. Res. Inst., 7: 131-136. 1975.

8) Nakanishi, T. and K. Suyama, Jap. J. Zootech. Sci., 37: 7-14. 1966.

9) Terkel, R. N. and R. W. Bray, J. Anim. Sci., 29: 288-293. 1969.

10) Dryden, F. D, and J. A. Marchello, J. Anim. Sci., 31: 36-41. 1970.

11) Nakanishi, T. and K. Suyama, Jpn. J. Zootech. Sci., 37: 375-381. 1966. 
12) Otake, Y. and Y. Hoshino, Jpn. J. Zootech. Sci., 43: 625-631. 1972.

13) LaWrie, R. A., Meat Science, A. Wheaton and Co., p 109. 1974.

14) Hornstein, L., P. F. Crowe and R. Hiner, J. Food Sci., 32: 650-655. 1967.

15) Ozutsumi, K. and M. OKada, Jap. J. Zootech. Sci., 53: 116-123. 1982.

16) Allen, E., R. W. Bray and R. G. Cassens, J. Food Sci., 32: 20-25. 1967.

\title{
肥育期間中におけるホルスタイン種去勢牛の 最長筋肉内の脂肪酸分布について
}

\author{
小堤恭平・伊藤 健* ・ 川西隆智**
}

農林水産省草地試験場，杤木県西那須野町 329-27

*千葉県酪農センター，千葉県入街町 289-11

神奈川県畜産試験場, 神奈川県本郷海老名市 243-04

肥育期間中における最長筋肉の脂肪酸組成の变化およ び分布について知るために，放牧後 100 日間（3 頭）お よび 200 日間 (4頭) 肥育したホルスタイン種去勢牛 7 頭を供試した，各なの最長筋肉方ら，(第 $4,6,8,10$ お よび 12 胸椎と第 1,3 および第 5 腰椎) 全脂質を抽出し， その脂肪酸組成について調べた。 100 日間と200日間肥 育した牛の笳肉内の脂肪酸組成は統計的になんら相違は 見られなかっだ、しかしながら，肥育期間中にC 18:0
は若干減少し, C 18:1 は若干増加の椂子が篗察された。 第 4,6,8 および 10 胸椎の最長筋は第 12 胸椎と第 1 , 3 捛よび腰椎のそれと比較すると，C 16:0 と C 18:0 が 多く，C16:1，C18:1 おょび全不能和脂肪酸含量が少な いことが見いだされた．この脂肪酸組成の相違は最長筋 肉内に标ける成長速度の相違に関連があるものと推定さ れる.

日畜会辄，53(8)：559-564，1982 